\title{
Role of the endocannabinoid system in the mechanisms involved in the LPS-induced preterm labor
}

\author{
María Victoria Bariani, Ana Paula Domínguez Rubio, Maximiliano Cella, Juliana Burdet ${ }^{1}$, \\ Ana María Franchi and Julieta Aisemberg \\ Laboratory of Physiopathology of Pregnancy and Labor, Center for Pharmacological and Botanical Studies, National \\ Research Council, School of Medicine, University of Buenos Aires, Buenos Aires, Argentina and ${ }^{1}$ Laboratory of \\ Physiopathogeny, Department of Physiology, School of Medicine, University of Buenos Aires, Argentina \\ Correspondence should be addressed to MV Bariani; Email: vickiba_86@hotmail.com
}

\begin{abstract}
Prematurity is the leading cause of perinatal morbidity and mortality worldwide. There is a strong causal relationship between infection and preterm births. Intrauterine infection elicits an immune response involving the release of inflammatory mediators like cytokines and prostaglandins (PG) that trigger uterine contractions and parturition events. Anandamide (AEA) is an endogenous ligand for the cannabinoid receptors CB1 and CB2. Similarly to PG, endocannabinoids are implicated in different aspects of reproduction, such as maintenance of pregnancy and parturition. Little is known about the involvement of endocannabinoids on the onset of labor in an infectious milieu. Here, using a mouse model of preterm labor induced by lipopolysaccharide (LPS), we explored changes on the expression of components of endocannabinoid system (ECS). We have also determined whether AEA and CB antagonists alter PG production that induces labor. We observed an increase in uterine $\mathrm{N}$-acylphosphatidylethanolaminespecific phospholipase D expression (NAPE-PLD, the enzyme that synthesizes AEA) upon LPS treatment. Activity of catabolic enzyme fatty acid amide hydrolase (FAAH) did not change significantly. In addition, we also found that LPS modulated uterine cannabinoid receptors expression by downregulating $C b 2$ mRNA levels and upregulating CB1 protein expression. Furthermore, LPS and AEA induced PGF2a augmentation, and this was reversed by antagonizing CB1 receptor. Collectively, our results suggest that ECS may be involved in the mechanism by which infection causes preterm birth.

Reproduction (2015) $150463-472$
\end{abstract}

\section{Introduction}

Prematurity is the leading cause of mortality and morbidity in neonates and children. It is well known that $\sim 30 \%$ of all premature deliveries occur in association with an underlying infectious process (Challis et al. 2001, Park et al. 2009). We have previously developed a murine model of lipopolysaccharide (LPS)induced preterm labor to mimic the pathological process implicated in prematurity induced by infections. Premature labor was induced by i.p. administration of LPS on day 15 of pregnancy. Exposure to bacterial endotoxin produces $100 \%$ of preterm birth with low incidence of maternal mortality (Cella et al. 2010, Domínguez Rubio et al. 2014).

Endocannabinoids are endogenous unsaturated bioactive fatty acid amides, ethers and esters that bind to and activate cannabinoid receptors CB1 and CB2. Anandamide (AEA) is synthesized on demand from membrane lipid precursors by the action of
$\mathrm{N}$-acylphosphatidylethanolamine-specific phospholipase D (NAPE-PLD) (Piomelli et al. 2000). The biological activity of AEA is terminated by its cellular uptake followed by its intracellular degradation by a fatty acid amide hydrolase (FAAH). The endocannabinoid system (ECS) has been implicated in different reproductive events in women (Paria et al. 1995, Habayeb et al. 2004, Taylor et al. 2007). Uterine tissue contains high concentrations of AEA (Schmid et al. 1997), and during labor blood AEA levels increase dramatically, suggesting a role for AEA in normal labor (Habayeb et al. 2004). Numerous studies have shown that LPS modulates the ECS in different ways depending on the cell type (Varga et al. 1998, Maccarrone et al. 2001).

Prostaglandins (PG) production plays a central role in preterm labor induced by intrauterine infection (Gross et al. 2000, Adams et al. 2008, Timmons et al. 2014). Accordingly, previous results from our laboratory have shown that LPS treatment increases uterine PG and 
cyclooxygenase levels (Cella et al. 2010, Domínguez Rubio et al. 2014).

On the basis of the evidence presented above, the aim of the present study was to investigate the effect of LPS on the ECS in a murine model of LPS-induced preterm labor as well as the relationship between uterine PG levels and ECS.

\section{Materials and methods}

\section{Reagents}

LPS from Escherichia coli, serotype 055:B5, HRP conjugated secondary antibody, anti-b-Actin antibody, FITC-conjugated secondary antibody and PGF2a antiserum were provided by Sigma-Aldrich Co. $\left[5,6,8,9,11,12,14,15(\mathrm{n}){ }^{3} \mathrm{H}\right]-\mathrm{PGF} 2 \mathrm{a}$ $(160 \mathrm{Ci} / \mathrm{mmol}, 200 \mu \mathrm{Ci} / \mathrm{ml})$ and $\left[5,6,8,9,11,12,14,15-{ }^{3} \mathrm{H}\right]-$ AEA $(172.4 \mathrm{Ci} / \mathrm{mmol}, 100 \mu \mathrm{Ci} / \mathrm{ml})$ were provided by PerkinElmer Life and Analytical Sciences, Inc. (Walthman, MA, USA). TLC aluminum silica gel plates were purchased from Merck KGaA (Darmstadt, Germany). AM251 (CB1 antagonist) was provided by Tocris Cookson, Inc. (Ellisville, MO, USA) and AM630 (CB2 antagonist) by Cayman Chemical Co. (Ann Arbor, $\mathrm{MI}$, USA). CB2 and NAPE-PLD primary antibody were purchased from Abcam, Inc. (Cambridge, MA, USA) and CB1 primary antibody from Enzo Life Sciences, Inc. (Farmingdale, NY, USA). FAAH primary antibody was a kind gift from Benjamin Cravatt (Department of Chemical Physiology, The Skaggs Institute for Chemical Biology, The Scripps Research Institute, La Jolla, CA 92037, USA). Western blotting reagents and nitrocellulose membranes (Trans-Blot, $0.45 \mu \mathrm{m}$ ) were from Bio-Rad Inc. and molecular weight marker was purchased from GE Healthcare Bio-Science Corp. (Piscataway, NJ, USA). TRI Reagent, dNTPs and ribonuclease inhibitor were from Genbiotech (Buenos Aires, Argentina). Ultrapure water, DTT, RNAse free DNAse 1, Moloney Murine Leukemia virus reverse transcriptase (M-MLVRT) and random primers were purchased from Invitrogen. GoTaq DNA polymerase was provided by Promega. All other chemicals were of analytical grade.

\section{Animals}

Virgin $B A L B / C$ female mice (8-12 weeks old; $25-30 \mathrm{~g}$ of weight) were paired with fertile males of the same strain. Day of vaginal plug detection was considered as day 0 of pregnancy. Under our animal facility conditions, normal term labor occurs at day 19 of pregnancy. Animals received a regular supply of food and water and allowed to feed and drink ad libitum and were housed under controlled conditions of light $(12 \mathrm{~h}$ light: $12 \mathrm{~h}$ darkness cycle) and temperature $\left(23-25^{\circ} \mathrm{C}\right)$.

Mice were euthanized by $\mathrm{CO}_{2}$ inhalation. The experimental procedures reported here were approved by the Animal Care Committee of the Center for Pharmacological and Botanical Studies, National Research Council, and by the Institutional Committee for the Care and Use of Laboratory Animals (CICUAL) from the School of Medicine, University of Buenos Aires, and were carried out in accordance.

\section{Murine model of preterm labor}

$B A L B / c$ mice on day 15 of pregnancy were injected i.p. with two doses of vehicle (sterile saline solution) or LPS (Escherichia coli, 055:B5), the first one $(0.26 \mathrm{mg} / \mathrm{kg}, 10 \mu \mathrm{g}$ in $0.1 \mathrm{ml}$ of vehicle) at $1000 \mathrm{~h}$ and the second at $1300 \mathrm{~h}(0.52 \mathrm{mg} / \mathrm{kg}, 20 \mu \mathrm{g}$ in $0.1 \mathrm{ml}$ of vehicle) (Cella et al. 2010). Preterm labor occured in $100 \%$ of the animals during the night of day 15 and the morning of day 16, without affecting maternal health. The beginning of preterm labor was defined by the delivery of the first pup.

\section{RT-PCR}

Animals were euthanized on day 15 of pregnancy $5 \mathrm{~h}$ after the second vehicle or LPS injection. The uterus was immediately removed and cleaned. Decidua was separated and discarded. TRI Reagent was added to samples and tissues were homogenized and frozen at $-80^{\circ} \mathrm{C}$ until used. Total RNA from uterine strips was isolated according to manufacturer's recommendations (Molecular Research Center, Inc., Cincinnati, $\mathrm{OH}, \mathrm{USA}$ ). Following extraction, RNA was quantified and cDNA was synthesized from total RNA ( $3 \mu \mathrm{g}$ ) using M-MLVRT, random primers and ribonuclease inhibitor. Specific primers were designed using the Primer3 Software (Rozen \& Skaletsky 2000). Primers sequences and PCR conditions are shown in Table 1. Products were loaded onto $2 \%$ agarose gel and stained with ethidium bromide. Bands were visualized on a transilluminator under UV light. Photographs were taken with a digital camera (Olympus C-5060) and analyzed using the freely available Image J Software Package. Relative mRNA level was normalized to $b$-Actin and results were expressed as relative optical density (Faah/b-Actin, Nape-pld/b-Actin, Cb1/b-Actin, Cb2/b-Actin).

\section{Western blot analysis}

A group of animals was euthanized on day 13,15, 18 or 19 of pregnancy whereas another was euthanized on day 15 of pregnancy $7 \mathrm{~h}$ after second vehicle or LPS injection. The uteri were immediately removed and homogenized (Ultra Turrax, T25 basic, IKA Labortechnik, Staufen, Germany) in lysis buffer $(10 \mathrm{mM}$ Hepes, $5 \mathrm{mM} \mathrm{MgCl}$, $142.5 \mathrm{mM} \mathrm{KCl}, 0.1 \%$ SDS, $1 \%$ Nonidet-40, $5 \mathrm{mM}$ EDTA, 0.5\% sodium deoxycholate in PBS) with a freshly added protease inhibitor cocktail $(10 \mu \mathrm{g} / \mathrm{ml}$ leupeptin, $2 \mu \mathrm{g} / \mathrm{ml}$ aprotinin, $100 \mu \mathrm{g} / \mathrm{ml}$ soybean-trypsin inhibitor, $1 \mathrm{mmol} / \mathrm{l}$ EDTA, $1 \mathrm{mg} / \mathrm{ml}$ benzamidine, $10 \mu \mathrm{g} / \mathrm{ml}$ DTT and $1 \mathrm{mg} / \mathrm{ml}$ caproid acid). Tissues were sonicated (Ultrasonic Cell Disrupter, Microson, Heat systems, Inc. New York, NY, USA) for $30 \mathrm{~s}$, centrifuged at $1500 \mathrm{~g}$ for $10 \mathrm{~min}$ and protein concentration determined by Bradford assay (Bradford 1976). Eighty micrograms of protein were loaded in each lane. Positive controls were mouse liver for FAAH, mouse brain for NAPE-PLD and CB1 and mouse spleen for CB2. Samples were separated by electrophoresis in $7.5 \%-$ $12 \%$ SDS-PAGE gel and transferred to a $0.45 \mu \mathrm{m}$ nitrocellulose membrane. Membranes were blocked using $5 \% \mathrm{w} / \mathrm{v}$ dried nonfat milk and then incubated with the primary antibodies. Dilution of antibodies and incubation conditions are shown in 
Table 1 Primer sequences and PCR conditions used for RT-PCR in uteri from BALB/c mice.

\begin{tabular}{|c|c|c|}
\hline mRNA & Primers & Conditions \\
\hline \multirow[t]{2}{*}{$\beta$-Actin } & Forward 5'-TGT TAC CAA CTG GGA CGA CA-3' & $94{ }^{\circ} \mathrm{C} 5 \min \left(94{ }^{\circ} \mathrm{C} 40 \mathrm{~s}, 57^{\circ} \mathrm{C} 30 \mathrm{~s}, 72^{\circ} \mathrm{C} 1 \mathrm{~min}\right) \times 30$ \\
\hline & Reverse 5'-TCT CAG CTG TGG TGG TGA AG-3' & $72{ }^{\circ} \mathrm{C} 5 \min$ \\
\hline \multirow[t]{2}{*}{ Faah } & Forward 5'-GAG ATG TAT CGC CAG TCC GT-3' & $94{ }^{\circ} \mathrm{C} 5 \min \left(94{ }^{\circ} \mathrm{C} 40 \mathrm{~s}, 54{ }^{\circ} \mathrm{C} 40 \mathrm{~s}, 72{ }^{\circ} \mathrm{C} 40 \mathrm{~s}\right) \times 34$ \\
\hline & Reverse 5'-ACA GGC AGG CCT ATA CCC TT-3' & $72{ }^{\circ} \mathrm{C} 5 \mathrm{~min}$ \\
\hline \multirow[t]{2}{*}{ Nape-pld } & Forward 5'-ATG AGA ACA GCC AGT CTC CA-3' & $94{ }^{\circ} \mathrm{C} 5 \min \left(94^{\circ} \mathrm{C} 40 \mathrm{~s}, 57^{\circ} \mathrm{C} 1 \mathrm{~min}, 72^{\circ} \mathrm{C} 1 \mathrm{~min}\right) \times 35$ \\
\hline & Reverse 5'-CCA TTT CCA CCA TCA GCG TC-3' & $72{ }^{\circ} \mathrm{C} 5 \min$ \\
\hline \multirow[t]{2}{*}{ Cb1 } & Forward 5'-ACC TGA TGT TCT GGA TCG GA-3' & $94{ }^{\circ} \mathrm{C} 5 \min \left(94{ }^{\circ} \mathrm{C} 15 \mathrm{~s}, 55^{\circ} \mathrm{C} 30 \mathrm{~s}, 72{ }^{\circ} \mathrm{C} 30 \mathrm{~s}\right) \times 35$ \\
\hline & Reverse 5'-TGT TAT CTA GAG GCT GCG CA-3' & $72{ }^{\circ} \mathrm{C} 5 \min$ \\
\hline \multirow[t]{2}{*}{$C b 2$} & Forward 5'-TCT GTG TTA CCC GCC TAC CT-3' & $95^{\circ} \mathrm{C} 5 \min \left(95^{\circ} \mathrm{C} 1 \mathrm{~min}, 60^{\circ} \mathrm{C} 1 \mathrm{~min}, 75^{\circ} \mathrm{C} 1 \mathrm{~min}\right) \times 40$ \\
\hline & Reverse 5'-GTG GGG AAA GCT CAG AGC AG-3' & $75^{\circ} \mathrm{C} 5 \mathrm{~min}$ \\
\hline
\end{tabular}

Faah, Fatty acid amide hydrolase; Nape-pld, N-acyl phosphatidylethanolamine specific phospholipase D; Cb1,Cannabinoid receptor type 1; Cb2,Cannabinoid receptor type 2.

Table 2. Membranes were washed with PBS-T (10 mM Tris, $100 \mathrm{mM} \mathrm{NaCl}$ and $0.1 \%$ Tween $20, \mathrm{pH} 7.5$ ) followed by $1 \mathrm{~h}$ incubation with HRP-conjugated anti-rabbit secondary antibody (1:3000) and developed using the ECL system. Images for immunoreactive bands were acquired using the ImageQuant blot documentation instrument (GE Healthcare Life Sciences, Pittsburgh, PA, USA) and analyzed using the Image J Software Package (developed at the National Institutes of Health, free download available at http://rsbweb.nih.gov/ij/). Relative protein level was normalized to $\beta$-ACTIN and results were expressed as relative optical density (FAAH/ $\beta-A C T I N$, NAPE-PLD/ $\beta-A C T I N, C B 1 / \beta-A C T I N, C B 2 / \beta-A C T I N)$.

\section{Determination of FAAH activity}

FAAH activity was assayed as described by Paria et al. (1996) with minor modifications. Uteri from mice on day 15 of pregnancy treated with vehicle or LPS $(3,5$ or $7 \mathrm{~h}$ after second injection) were homogenized (Ultra Turrax, T25 basic, IKA Labortechnik) in Tris- $\mathrm{HCl} 20 \mathrm{mM}(\mathrm{pH}=7.6)$ buffer containing EDTA $1 \mathrm{mM}$ and protein concentration determined by the Bradford assay (Bradford 1976). One hundred $\mathrm{mg}$ of protein were incubated at $37^{\circ} \mathrm{C}$ for $15 \mathrm{~min}$ in $200 \mu \mathrm{l}$ Tris/ $\mathrm{HCl} 50 \mathrm{mM}$ $(\mathrm{pH}=8.5)$ buffer whit $100 \mu \mathrm{M}\left[{ }^{3} \mathrm{H}\right]-\mathrm{AEA}$ and 20 nmols AEA. The reaction was stopped adding a mix of chloroform:methanol $(1: 1 \mathrm{v} / \mathrm{v})$. The aqueous phase was extracted twice with chloroform. Samples were dried and resuspended in chloroform and were plated on silica TLC plates Gel 60. A solvent mixture (ethyl acetate:hexane:acetic acid:distilled water, 100:50:20:100 v/v) was flowed through the plate. Lipids were visualized with iodine vapor and were identified by co-migration with AEA and arachidonic acid (AA) standards. Radioactivity was counted in a b-scintillation counter. The area of each radioactive peak corresponding to AA was calculated and expressed as a percentage of the total radioactivity of the plates. Enzyme activity is reported as nmol AA/h/mg protein.

\section{Hematoxilin-eosin (H\&E) histological staining and immunofluorescence}

Uteri and ovaries from mice on day 15 of pregnancy treated with vehicle or LPS ( $7 \mathrm{~h}$ after second injection) and ovaries from mice on day 18 of pregnancy were fixed in $4 \%$ formaldehyde. Fixed tissues were dehydrated in an increasing gradient of alcohol and embedded in paraffin. Sections of $4 \mu \mathrm{m}$ were obtained and mounted on silanized slides. Ovaries were stained with H\&E to evaluate its morphology and the proportion of large and small cells of the total luteal cells population. Also, uterine tissue section slides were stained with $\mathrm{H} \& \mathrm{E}$ for quality control. Uterine tissues slides were de-waxed and rehydrated. Endogenous peroxidase enzyme activity were eliminated by the addition of $0.3 \%$ hydrogen peroxide $(\mathrm{v} / \mathrm{v})$ in methanol for $15 \mathrm{~min}$. Tissues slides were incubated with $5 \%$ fetal bovine serum-PBS in a moist chamber at room temperature for $1 \mathrm{~h} 30 \mathrm{~min}$. Tissues slides were incubated with primary antibody against CB1 $(1: 50)$ or CB2 $(1: 50)$ at $4{ }^{\circ} \mathrm{C}$ for $48 \mathrm{~h}$. After PBS washes, tissues slides were incubated whit antiFITC secondary antibody $(1: 200)$ at room temperature for $1 \mathrm{~h}$ $30 \mathrm{~min}$. Mounting medium Glycerol:PBS (1:1 v/v) was placed on the slide and were observed on a Nikon Eclipse E200 (Melville, NY, USA) binocular microscope.

\section{Progesterone electrochemiluminescence immunoassay}

Animals were anesthetized in a $\mathrm{CO}_{2}$ atmosphere on day 15 of pregnancy 3, 5 or $7 \mathrm{~h}$ after second vehicle or LPS injection and blood was collected by decapitation. Blood was allowed to clot and was centrifuged at $0.8 \mathrm{~g}$ for $10 \mathrm{~min}$ to separated serum. Progesterone serum levels were determined by electrochemiluminescence immunoassay (ECLIA). Progesterone serum levels are reported as ng of progesterone/ml serum.

Table 2 Dilution of antibodies and incubation conditions used for western blot analysis in uteri from BALB/c mice.

\begin{tabular}{llc}
\hline Antibody & Dilution & Incubation \\
\hline FAAH & $1 / 250$ & $36 \mathrm{~h} \mathrm{a} 4{ }^{\circ} \mathrm{C}$ \\
NAPE-PLD & $1 / 1500$ & $36 \mathrm{~h} \mathrm{a} 4{ }^{\circ} \mathrm{C}$ \\
CB2 & $1 / 300$ & $36 \mathrm{~h} \mathrm{a} 4{ }^{\circ} \mathrm{C}$ \\
CB1 & $1 / 200$ in $5 \% \mathrm{BSA}$ & $18 \mathrm{~h} \mathrm{a} 4{ }^{\circ} \mathrm{C}$ \\
$\beta$-Actin & $1 / 4000$ & 15 min at room \\
& & temperature \\
\hline
\end{tabular}

FAAH, Fatty acid amide hydrolase;NAPE-PLD, N-acyl phosphatidylethanolamine specific phospholipase D; CB1, Cannabinoid receptor type 1; CB2, Cannabinoid receptor type 2. 

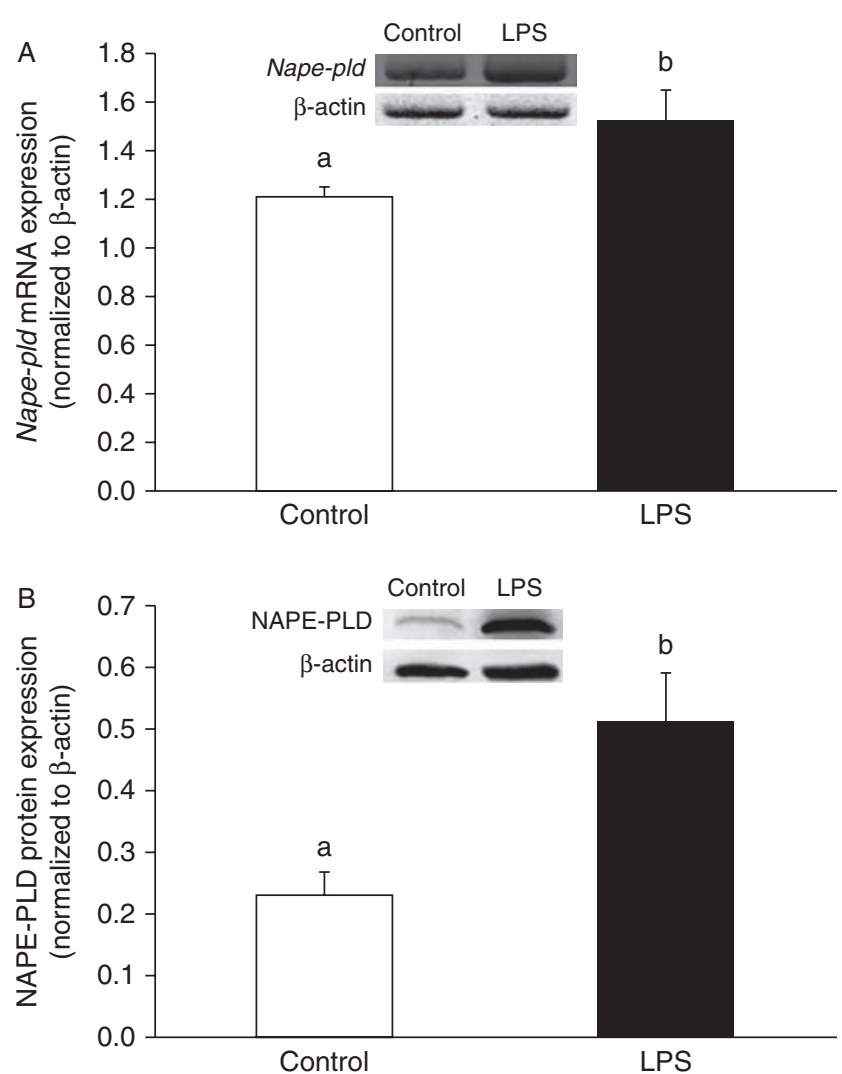

Figure 1 Effect of LPS on NAPE-PLD expression. BALB/c female mice in day 15 of pregnancy were injected with LPS or saline solution (control) and uterine strips were collected. Nape-pld mRNA (A) or protein (B) levels were measured at 5 or $7 \mathrm{~h}$ after the second LPS injection, respectively. Data are mean \pm S.E.M. $(n=6)$. Bars with different superscript letters denote significant differences. $P<0.05$ by Tukey's test, $\mathrm{a} \neq \mathrm{b}$. Representative images of Nape-pld mRNA and protein levels are shown in panel A and B respectively.

\section{PGF2a RIA}

Animals were euthanized $7 \mathrm{~h}$ after the second vehicle or LPS injection. Uterine strips were incubated in Krebs - Ringer Bicarbonate buffer (KRB: $\mathrm{NaCl} 118 \mathrm{mM}, \mathrm{KCl} 4.7 \mathrm{mM}, \mathrm{KH}_{2} \mathrm{PO}_{4}$ $1.18 \mathrm{mM}, \mathrm{MgSO}_{4} \cdot 7 \mathrm{H}_{2} \mathrm{O} 1.22 \mathrm{mM}, \mathrm{NaHCO}_{3} 25 \mathrm{mM}$, glucose $11.1 \mathrm{mM}$ ) at $37{ }^{\circ} \mathrm{C}$ for $1 \mathrm{~h}$ in a $95 \% \mathrm{O}_{2} / 5 \% \mathrm{CO}_{2}$ atmosphere. In some cases, incubation was performed in the presence of cannabinoid receptors antagonist AM630 and AM251 (CB1 and $\mathrm{CB} 2$ antagonist respectively) at different concentrations $\left(10^{-6} \mathrm{M} ; 10^{-7} \mathrm{M} ; 10^{-8} \mathrm{M}\right.$ and $\left.10^{-9} \mathrm{M}\right)$ or in the presence of AEA at different concentrations $\left(10^{-6} \mathrm{M} ; 10^{-7} \mathrm{M}\right.$ and $\left.10^{-9} \mathrm{M}\right)$. For the following experiments, the lower concentration in which we observed changes was used. Protein concentration was determinate by Bradford assay (Bradford 1976). Medium was acidified to $\mathrm{pH} 3$ with $1 \mathrm{M} \mathrm{HCl}$. Two milliliters of ethyl acetate were added to KRB and organic phase was extracted three times. Pooled ethyl acetate extracts were dried. PGF2a concentration was determined by RIA (Campbell \& Ojeda 1987). PGF2a antiserum was highly specific for PGF2a and showed low cross-reactivity with related compounds. Sensitivity was $5-10 \mathrm{pg}$ per tube and $\mathrm{Ka}=1.5 \times 10^{10} \mathrm{I} / \mathrm{mol}$. Values were expressed as pg of PGF2a/mg of protein.

\section{Statistical analysis}

Results were analyzed by one-way ANOVA (LPS or AEA) or by two-way ANOVA (LPS and CB receptor antagonists or AEA and $\mathrm{CB}$ receptor antagonists) in a completely randomized design. Comparisons were made with the Tukey's test. Results were considered significant at $P<0.05$. The assumptions of normality and homogeneity of variance were analytically assessed by the Shapiro-Wilks test and the Levene test respectively. All statistical analyses were performed using the statistical program Infostat (FCA, University of Córdoba, Argentina).

\section{Results}

\section{Effect of LPS on AEA metabolism}

We began analyzing the effect of LPS treatment on AEA biosynthesis in uterine tissue. We observed an increase in Nape-pld mRNA (Fig. 1A) and protein expression (Fig. 1B) in uteri from LPS-treated mice when compared to control mice. Next, we evaluated FAAH activity in uteri tissue from LPS-treated and control females. Figure 2 shows that uterine FAAH activity did not change significantly after LPS treatment.

\section{Expression and localization of cannabinoid receptors in murine uterus during pregnancy. Effects of LPS administration}

We observed that both $\mathrm{CB} 1$ and $\mathrm{CB} 2$ receptors were expressed in uterus (Fig. 3A and $\mathrm{B}$ respectively) and there was no change in their protein expression from day 13 to day 19 of pregnancy.

Even though we did not find changes in $C b 1$ mRNA levels, we found an increase in the protein expression

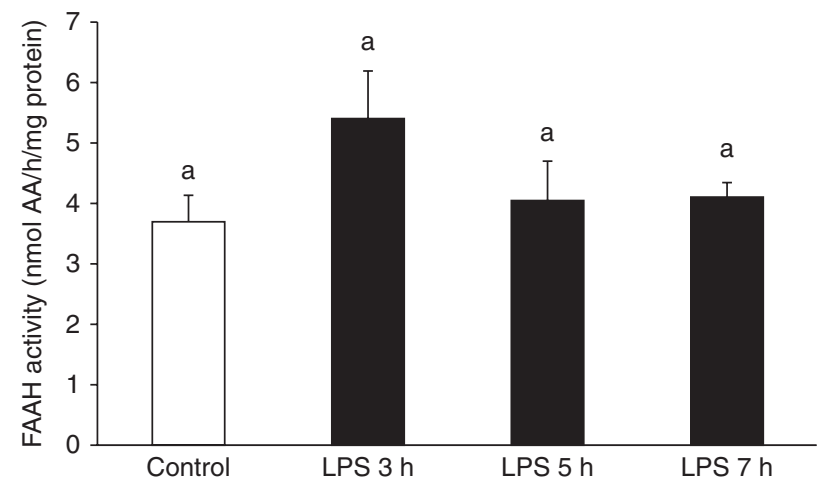

Figure 2 Effect of LPS on FAAH activity. BALB/c female mice in day 15 of pregnancy were injected with LPS or saline solution (control) and uterine strips were collected at 3,5 or $7 \mathrm{~h}$ after the second LPS injection, and FAAH activity was measured. Data are mean \pm s.E.M. $(n=8) . P<0.05$ by Tukey's test. 

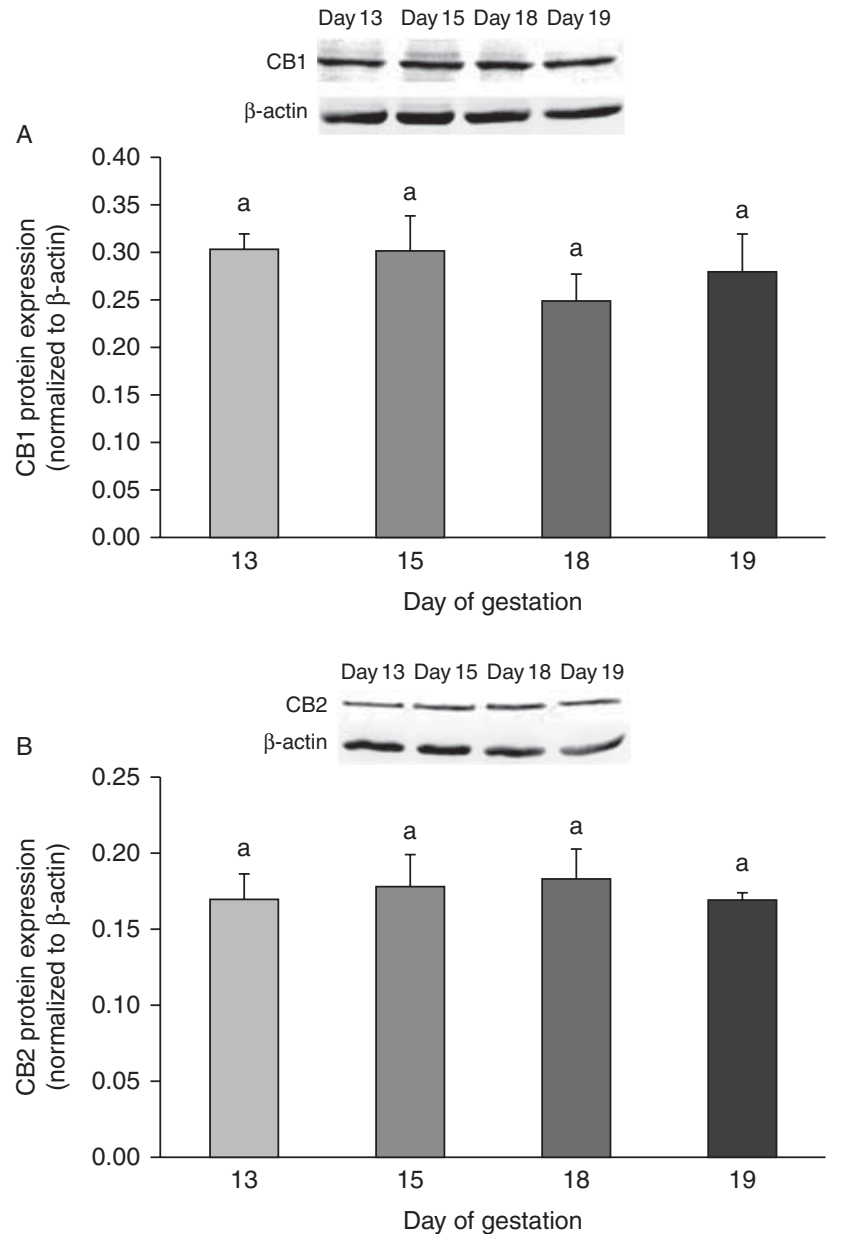

Figure 3 Presence of cannabinoids receptors in mice uterus during late pregnancy. Uterine strips from $B A L B / c$ female mice were collected on day $13,15,18$ or 19 of pregnancy, and CB1 (A) and CB2 (B) protein levels were measured. Data are mean \pm S.E.M. $(n=5) . P<0.05$ by Tukey's test. Representative images of CB1 and CB2 protein levels are shown in panel $A$ and $B$ respectively.

of this receptor after LPS treatment (Fig. 4A and B). Interestingly, we observed a decrease in Cb2 mRNA expression in uteri of pregnant mice after the last LPS injection (Fig. 4C), albeit no changes at the protein levels were observed (Fig. 4D).

Positive immunoreactivity tissue sections for CB1 and CB2 were detected in uteri from LPS-treated and control females. Specifically, staining was restricted to the apical membrane of endometrial epithelial cells, with no staining on the endometrial stromal cells, myometrium and serous. We did not find changes in the uterine localization of cannabinoid receptors between treatments (Fig. 5A and B).

\section{Effect of LPS on maternal serum progesterone levels}

To evaluate whether LPS treatment affects maternal progesterone serum levels, we measured this hormone on day 18 of pregnancy (at term) and day 15 of
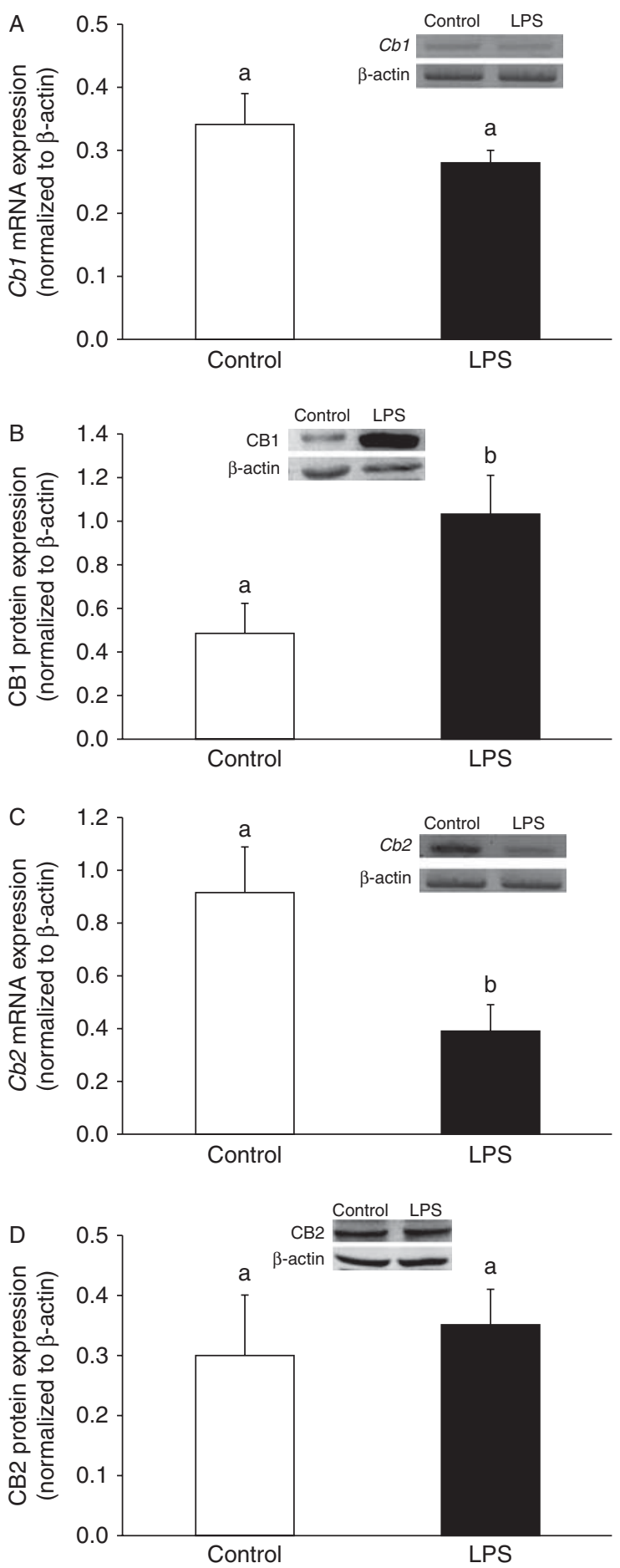

Figure 4 Effect of LPS on cannabinoids receptors expression. BALB/C female mice in day 15 of pregnancy were injected with LPS or saline solution (control) and uterine strips were collected at $5 \mathrm{~h}$ for mRNA or $7 \mathrm{~h}$ for protein determination after the second injection. (A) Cb1 mRNA levels $(n=8)$. (B) CB1 protein levels $(n=6)$. (C) Cb2 mRNA levels $(n=5)$. (D) CB2 protein levels $(n=6)$. Data are mean \pm S.E.M. Bars with different superscript letters denote significant differences. $P<0.05$ by Tukey's test, $\mathrm{a} \neq \mathrm{b}$. Representative images of $C b 1 \mathrm{mRNA}, \mathrm{CB} 1$ protein, Cb2 mRNA and CB2 protein levels are shown in panel A, B, C and D respectively. 

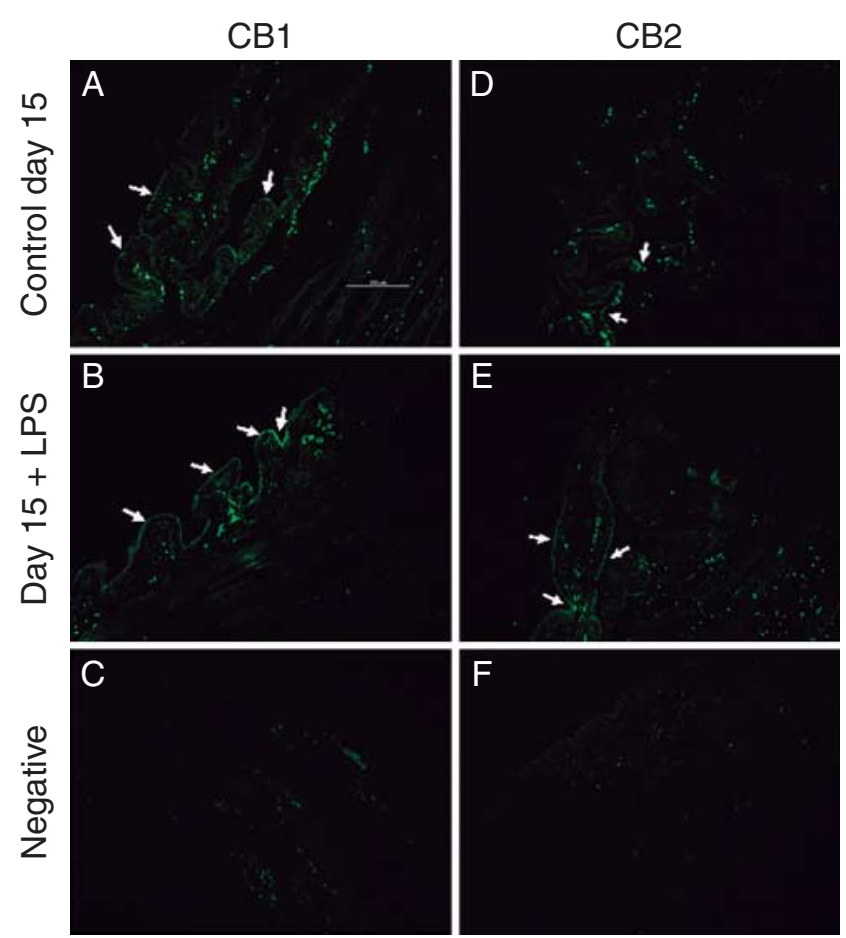

Figure 5 Effect of LPS on CB1 and CB2 uterine localization. Representative immunofluorescence for CB1 (A, B and C) and CB2 $(D, E$ and $F$ ) in uterine strips from $B A L B / C$ female mice in day 15 of pregnancy injected with saline solution (control) (A and D) or LPS ( $B$ and $\mathrm{E}$ ). These were collected at $7 \mathrm{~h}$ after the second injection. Arrows indicates endometrial epithelial cell positive for CB1 or CB2. In negative control the primary antibody is not added ( $C$ and $F$ ). Sections were visualized using fluorescence optical microscope (200× magnification).

pregnancy in LPS-treated and control mice. As expected, prior to delivery maternal progesterone serum levels decreased at day 18 of pregnancy. LPS treatment did not have any effect on progesterone serum levels on day 15 of pregnancy (Fig. 6).

\section{Effect of LPS on ovary morphology and luteal cell types}

Ovarian tissue sections were stained with H\&E and histopathological analysis was performed. Figure 7 shows that ovaries from mice treated with LPS presented intact tissular and cellular structure (Fig. 7C and F). We observed that ovaries from mice on day 18 of pregnancy (Fig. 7A and D) displayed a smaller population of large cells compared with ovaries from mice on day 15 of pregnancy (Fig. 7B and E). However, we did not find any differences in luteal cell types between LPS-treated and control females on day 15 of pregnancy.

\section{Relationship between uterine PGF2a levels and ECS}

As expected, we observed that PGF2a levels increased in uteri from LPS-treated mice (Fig. 8). The presence of CB2 receptor antagonist did not block PGF2a augmentation, whereas CB1 antagonist $\left(10^{-8} \mathrm{M}\right)$ abrogated LPS induced PGF2a increment (Fig. 8). Next, we decided to analyze whether AEA modulates PGF2a levels in this organ. Therefore, we measured PGF2a in uteri from day 15 pregnant mice incubated with different concentrations of AEA. Figure 9A showed an increase in uterine PGF2a levels at all analyzed concentrations. To evaluate which cannabinoid receptor was involved, we used the lower concentration of AEA $\left(10^{-9} \mathrm{M}\right)$ that caused an effect on PGF2a levels. We co-incubated uteri from day 15 pregnant mice with AEA and AM251 or AM630 (CB1 and $\mathrm{CB} 2$ receptor antagonist respectively). PGF2a augmentation was reversed in the presence of CB1 receptor antagonist $\left(10^{-8} \mathrm{M}\right)$ (Fig. 9B), whereas incubation with AM630 had no effects (data not shown).

\section{Discussion}

Here we evaluated whether LPS affects the ECS in a model of endotoxin-induced preterm labor. Our results suggest that the ECS is involved in the mechanisms triggered by LPS that culminates with preterm labor.

Several studies have examined the expression and role of cannabinoid receptors in the reproductive system (Dennedy et al. 2004, El-Talatini et al. 2009, Fonseca et al. 2009). We are the first group to demonstrate the presence of uterine cannabinoid receptors in the late pregnancy in mice. We show their localization and expression in our LPS-induced preterm labor model.

The immunoreactivity of both receptors was restricted to the apical membrane of endometrial epithelial cells and no changes in CB1 or CB2 localization among treatments were observed. Schuel et al. (2002) reported the presence of AEA and others $\mathrm{N}$-acylethanolamines in human reproductive fluids, including follicular fluid. Therefore, the localization of CB1 and CB2 on the apical membrane of endometrial epithelial cells suggests the

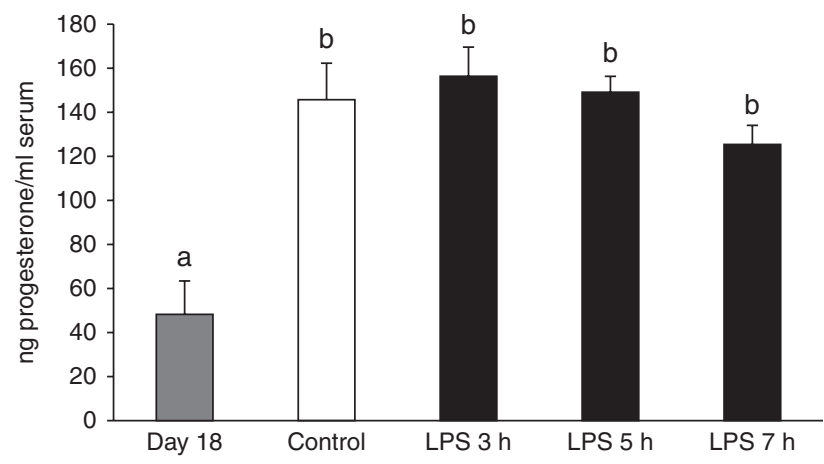

Figure 6 Effect of LPS on maternal serum progestrone levels. BALB/c female mice in day 15 of pregnancy were injected with LPS or saline solution (control) and blood were collected at 3, 5 or $7 \mathrm{~h}$ after the second injection to measure serum $P$ levels by ECLIA. Sera from mice on day 18 of pregnancy were used as controls of term delivery. Data are mean \pm s.E.M. $(n=8)$. Bars with different superscript letters denote significant differences. $P<0.05$ by Tukey's test, $\mathrm{a} \neq \mathrm{b}$. 


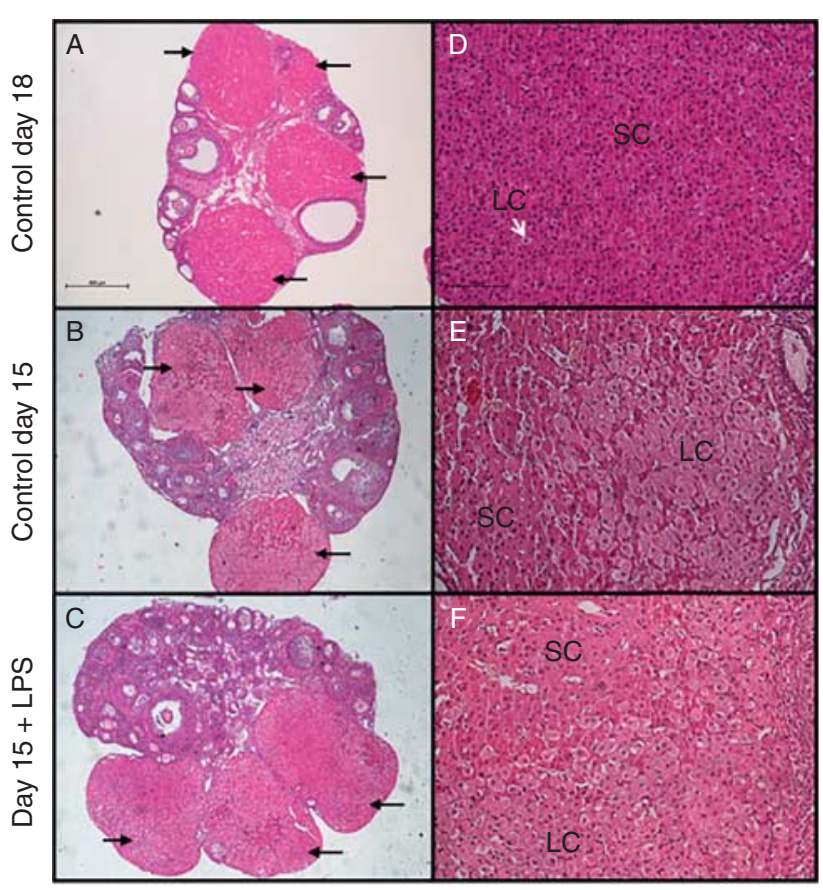

Figure 7 Effect of LPS on ovary morphology and luteal cell types. $B A L B / c$ female mice in day 15 of pregnancy were injected with LPS or saline solution (control) and ovaries were collected at $7 \mathrm{~h}$ after the second injection to perform H\&E staining. Ovaries from mice on day 18 of pregnancy were used as controls of term delivery. Sections were visualized using optical microscope. Arrows indicates corpora lutea. $\mathrm{SC}=$ small cells. $\mathrm{LC}=$ large cells. $\mathrm{A}, \mathrm{B}$ and $\mathrm{C}$ were evaluated at $40 \times$ magnification and D, E and F were evaluated at $200 \times$ magnification.

availability of these receptors to the AEA present in the uterine fluids. Interestingly, no staining was observed in endometrial stromal cells, myometrium and serous.

Several studies suggest the involvement of CB1 receptor in the regulation of labor. Wang et al. (2008) observed that genetic or pharmacological inactivation of CB1, but not CB2, induced preterm labor in C57BL/6J mice, thus suggesting that endocannabinoid signaling via CB1 is critical for a normal gestational length. In contrast, when we evaluated the cannabinoid receptors expression in our model of LPS-induced preterm labor, we observed an increased in CB1 receptor protein levels in uteri of pregnant mice after LPS injection. Therefore, the mechanism triggering preterm labor in this model seems to involve the activation of ECS through an increase on CB1 expression.

Recently, Sun et al. (2014) reported the participation of $\mathrm{CB} 2$ in regulating inflammation-driven preterm birth. The authors showed that CB2-, but not CB1-deficient mice are resistant to LPS-driven preterm birth. Here, we showed a downregulation of Cb2 receptor at mRNA levels in uteri of pregnant mice upon LPS injection, albeit no changes in CB2 receptor expression at protein. It is well known that $\mathrm{CB} 2$ receptors are expressed in immune, hematopoietic and in almost all peripheral blood immune cells (Pacher \& Mechoulam 2011), and its expression can be influenced by various inflammatory agents, e.g., LPS (Carlisle et al. 2002, Klein et al. 2003). Sun et al. (2014) observed that CB2-KO mice had higher serum levels of IL-10 and lower levels of pro-inflammatory cytokines in response to LPS challenge compared with WT controls.

The levels of AEA are regulated by a balance between the expression or activity of synthesizing (NAPE-PLD) and degrading (FAAH) enzymes. Furthermore, there is evidence that NAPE-PLD and/or FAAH expression and/or activity change in a spatiotemporal manner, determining AEA levels in different reproductive tissues such as oviduct, uterus and placenta (Guo et al. 2005, Maccarrone 2009, Fonseca et al. 2010). We are the first group to show uterine NAPE-PLD changes in the last part of pregnancy in mice. Here we demonstrated that, as we have previously shown for early pregnancy stages (Vercelli et al. 2009), LPS increases Nape-pld mRNA and protein expression in the uterus in the late stages of pregnancy. This finding correlates with Liu et al. (2003), who have demonstrated that LPS increases NAPE-PLD activity and AEA levels in RAW264.7 mouse macrophages. In addition, Shynlova et al. (2013) have observed that the numbers of neutrophils and macrophages were increased in myometrium in a mice model of preterm labor induced by endotoxin. Therefore, the changes we observed may be due not only to the changes produced in the murine uterus, but also to the modifications in the immune cells infiltrated in this tissue.

Several studies suggest an important role for FAAH in the maintenance and successfulness of a normal pregnancy (Wang et al. 2006). A lower enzymatic

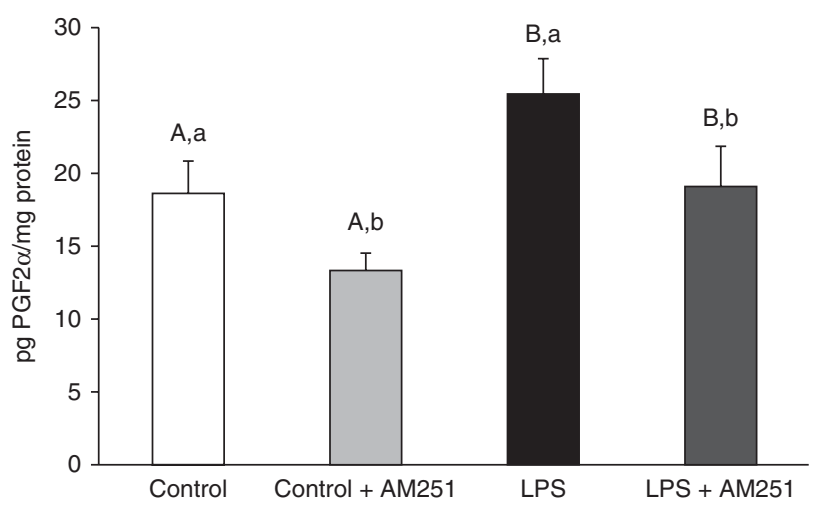

Figure 8 Relationship between uterine prostaglandin F2a levels and ECS. $B A L B / \mathrm{c}$ female mice in day 15 of pregnancy were injected with LPS or saline solution (control) and uterine strips were collected at $7 \mathrm{~h}$ after the second injection to measure PGF2a by RIA. In some cases, tissue was incubated in the presence of AM251 (CB1 antagonist, $10^{-8}$ $M)$, either in control (control + AM251) or in LPS-treated uteri (LPS+ AM251). Data are mean \pm S.E.M. $(n=10)$. Bars with different superscript capital letters denote significant differences between in vivo treatment (LPS and saline solution) and bars with different superscript lowercase letters denote significant differences between in vitro treatment (with or without AM251). $P<0.05$ by Tukey's test, $A \neq B$ and $a \neq b$. 

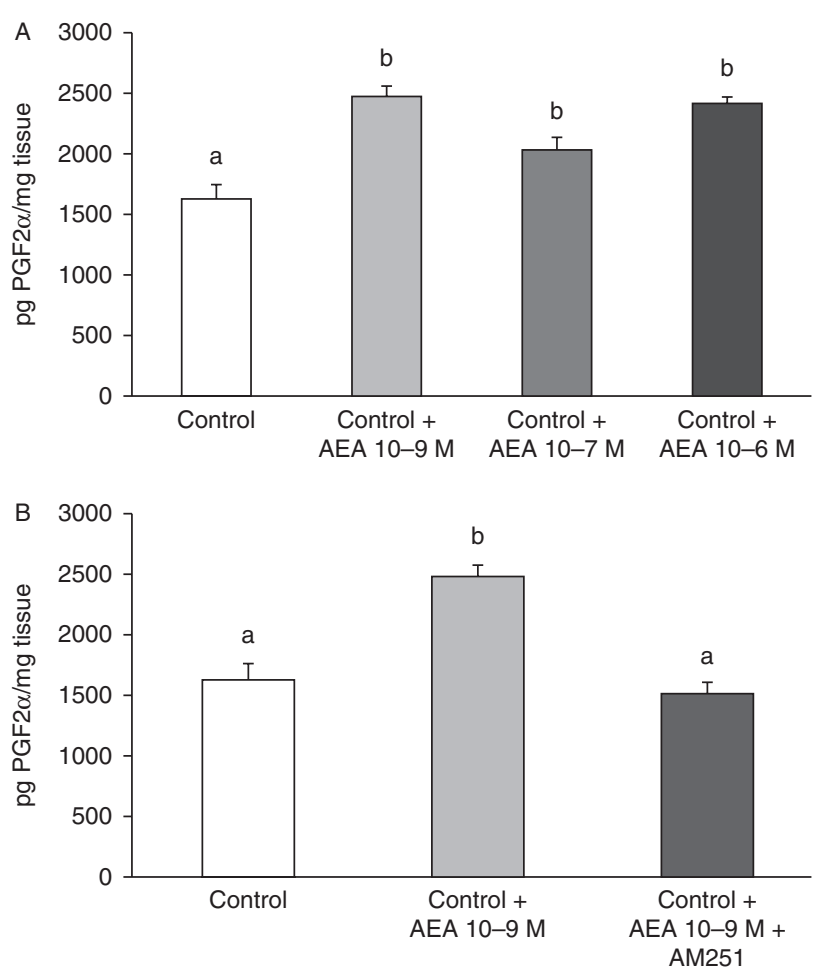

Figure 9 Effect of anandamide on uterine prostaglandin F2a levels. $B A L B / C$ female mice in day 15 of pregnancy were injected with saline solution (control) and uterine strips were collected at $7 \mathrm{~h}$ after the second injection to measure PGF2a by RIA. Tissue was incubated in the presence of AEA at different concentrations (A) or in presence of AEA $\left(10^{-9} \mathrm{M}\right)(\mathrm{control}+\mathrm{AEA})$ or AEA plus AM251 (CB1 antagonist, $\left.10^{-8} \mathrm{M}\right)$ (control +AEA +AM251) (B). Data are mean \pm s.E.M. $(n=10)(\mathrm{A})(n=10)$ (B). Bars with different superscript letters denote significant differences. $P<0.05$ by Tukey's test, $\mathrm{a} \neq \mathrm{b}$.

activity of FAAH has been described in peripheral lymphocytes from women who subsequently spontaneously miscarried (Maccarrone et al. 2000). Accordingly, placental tissues from spontaneously miscarrying women are characterized by very low FAAH levels (Trabucco et al. 2009). Conversely, there is a lack of data regarding the participation of FAAH on the pathophysiology of preterm labor. Several studies have shown that LPS affects FAAH activity and/or expression. Indeed, incubation of uterine explants from mice in day 7 of pregnancy with LPS increases FAAH activity (Vercelli et al. 2009), whereas in human peripheral lymphocytes, LPS downregulates FAAH expression and increases AEA levels (Maccarrone et al. 2001). We were unable to detect any changes in FAAH activity in our model of LPSinduced preterm labor. The discordance between our results and previous reports may suggest that both in vitro and in vivo regulation of FAAH are context-dependent and tissue-specific. Wolfson et al. (2013) observed that in vivo administration of LPS to non-pregnant mice decreased FAAH activity in peripheral blood mononuclear cells (PBMC), whereas in pregnant mice the endotoxin was unable to produce changes in PBMC's FAAH activity. The fact that we found increased expression of NAPE-LPD with no changes in FAAH activity points towards a possible rise of uterine AEA levels in this model. In this sense, Habayeb et al. (2004) have shown an increase in AEA plasma levels in women during labor, suggesting a participation of AEA during parturition.

The corpus luteum $(\mathrm{CL})$ is a transient endocrine gland that produces progesterone to maintain pregnancy in mice. Luteolysis includes loss of function and the involution of the morphology of CL. We observed that $\mathrm{CL}$ from mice at term (day 18) consisted mainly of small luteal cells with a lesser population of large cells, the main producers of $\mathrm{P}$, when compared to ovaries from mice on day 15 of pregnancy. Although it is well known that endotoxin induces luteolysis (Mishra \& Dhali 2007), we did not find effects of LPS on tissue and cellular structures or in the luteal cell types. The regression of $\mathrm{CL}$, directly associated with the onset of parturition in mice, occurs first as functional regression, associated with a marked decrease in progesterone synthesis.

We did not detect a decrease in maternal progesterone serum levels in mice treated with LPS. There are potential mechanisms involved in the reduction of $P R$ function in association with the onset of labor, as it occurs in humans that could be involved in our model of LPS-induced preterm labor (Mendelson 2009).

The ECS is also known to interact with gonadal steroid hormones. Lazzarin et al. (2004) have shown that changes in progesterone levels and FAAH expression are well correlated during the menstrual cycle. The CB2$K O$ mice are resistant to LPS-driven preterm birth and the endotoxin was unable to decrease maternal progesterone serum levels compared with WT mice (Sun et al. 2014), suggesting that ovaries deficient in CB2 are protected from adverse effects of inflammatory insults. In addition, in a model of LPS-induced embryonic resorption, the changes in FAAH activity correlated with changes in progesterone serum levels (Wolfson et al. 2013). In our model, we found no changes in maternal progesterone serum levels or in FAAH activity.

PG are crucial mediators in triggering preterm birth. Previous reports, although conflictingly, have determined the relationship between the ECS and PG (Chang et al. 2001, Mitchell et al. 2008, Vercelli et al. 2010). Indeed, it seems that this relationship varies greatly depending on the tissue as well as the studied species. In our model, LPS increased uterine PG and cyclooxygenase levels (Cella et al. 2010, Domínguez Rubio et al. 2014). Here, we show that the in vitro blockade of CB1 receptor decreased the uterine PGF2a levels in control and LPS-treated mice. Similarly to LPS, we observed that in vitro incubation with AEA produced an increase in uterine PGF2a levels. The results presented here suggest that LPS may not only increase CB1 expression but also AEA levels, which in turn, and 
by targeting CB1 receptors, increases PGF2a levels, as part of the mechanism that triggers LPS-induced preterm labor. It is important to note that AEA is metabolized by $\mathrm{FAAH}$ to ethanolamine and $\mathrm{AA}$, a precursor of $\mathrm{PG}$. However, PGF2a augmentation was blocked by the CB1 receptor antagonist AM251, suggesting that this effect occurs by AEA binding to CB1 and not by the metabolism of AEA into PG precursors. In keeping with this, Mitchell et al. (2008) showed that endocannabinoids and the synthetic cannabinoid CP55, 940 stimulated the fetal membrane production of PGE2 in a CB1 receptor-dependent manner. Taken together, our previous results as well as the ones presented here indicate that the ECS is able to modulate PG production.

Although there is a continuous effort to find different and inventive ways to address this problem, there are limited options to prevent preterm birth to date. Collectively, our data suggest the possible involvement of the ECS in LPS-induced preterm labor and that targeting this system could provide new therapeutic strategies for preventing preterm labor.

\section{Declaration of interest}

The authors declare that there is no conflict of interest that could be perceived as prejudicing the impartiality of the research reported.

\section{Funding}

This work was supported by Proyectos de Investigación en Ciencia y Tecnología 2010 no. 0813 and no. 0938 (FONCYT) and Proyecto de Investigación Plurianual 2012 no. 0061 (CONICET). The funders had no role in study design, data collection and analysis, decision to publish, or preparation of the manuscript.

\section{Acknowledgements}

We would like to thank Ramona Morales for technical support and Marcela Marquez and Daniel González for their dedication in the management of our mice at our animal facility. We are grateful to Benjamin Cravatt for the FAAH primary antibody.

\section{References}

Adams WKM, Persing D, Novy MJ, Sadowsky DW \& Gravett MG 2008 Pretreatment with toll-like receptor 4 antagonist inhibits lipopolysaccharide-induced preterm uterine contractility, cytokines, and prostaglandins in rhesus monkeys. Reproductive Sciences 15 121-127. (doi:10. 1177/1933719107310992)

Bradford MM 1976 A rapid and sensitive method for the quantitation of microgram quantities of protein utilizing the principle of protein-dye binding. Analytical Biochemistry 72 248-254. (doi:10.1016/00032697(76)90527-3)

Campbell WB \& Ojeda SR 1987 Measurement of prostaglandins by radioimmunoassay. Methods in Enzymology 141 323-341. (doi:10.1016/ 0076-6879(87)41080-x)
Carlisle SJ, Marciano-Cabral F, Staab A, Ludwick C \& Cabral GA 2002 Differential expression of the CB2 cannabinoid receptor by rodent macrophages and macrophages-like cells in relation to cell activation. International Immunopharmacology 2 69-82. (doi:10.1016/S15675769(01)00147-3)

Cella M, Farina MG, Domínguez Rubio AP, Di Girolamo G, Ribeiro ML \& Franchi AM 2010 Dual effect of nitric oxide on uterine prostaglandin synthesis in a murine model of preterm labour. British Journal of Pharmacology 161 844-855. (doi:10.1111/j.1476-5381.2010.00911.x)

Challis JR, Lye SJ, Gibb W, Whittle W, Patel F \& Alfaidy N 2001 Understanding preterm labor. Annals of the New Academy of Sciences 943 225-234. (doi:10.1111/j.1749-6632.2001.tb03804.x)

Chang YH, Lee ST \& Lin WW 2001 Effects of cannabinoids on LPS-stimulated inflammatory mediator release from macrophages: involvement of eicosanoids. Journal of Cellular Biochemistry $\mathbf{8 1}$ 715-723. (doi:10.1002/jcb.1103)

Dennedy MC, Friel AM, Houlihan DD, Broderick VM, Smith T \& Morrison JJ 2004 Cannabinoids and the human uterus during pregnancy. American Journal of Obstetrics and Gynecology 190 2-9. (doi:10.1016/j. ajog.2003.07.013)

Domínguez Rubio AP, Sordelli M, Salazar Al, Aisemberg J, Bariani MV, Cella M, Rosenstein RE \& Franchi AM 2014 Melatonin prevents experimental preterm labor and increases offspring survival. Journal of Pineal Research 56 154-162. (doi:10.1111/jpi.12108)

El-Talatini MR, Taylor AH, Elson JC, Brown L, Davidson AC \& Konje JC 2009 Localisation and function of the endocannabinoid system in the human ovary. PLoS ONE 4 e4579. (doi:10.1371/journal.pone.0004579)

Fonseca BM, Correia-da-Silva G, Taylor AH, Konje JC, Bell SC \& Teixeira NA 2009 Spatio-temporal expression patterns of anandamidebinding receptors in rat implantation sites: evidence for a role of the endocannabinoid system during the period of placental development. Reproductive Biology and Endocrinology 7 121. (doi:10.1186/14777827-7-121)

Fonseca BM, Correia-da-Silva G, Taylor AH, Lam PM, Marczylo TH, Konje JC, Bell SC \& Teixeira NA $2010 \mathrm{~N}$-acylethanolamine levels and expression of their metabolizing enzymes during pregnancy. Endocrinology 151 3965-3974. (doi:10.1210/en.2009-1424)

Gross G, Imamura T, Vogt SK, Wozniak DF, Nelson DM, Sadovsky Y \& Muglia LJ 2000 Inhibition of cyclooxygenase-2 prevents inflammationmediated preterm labor in the mouse. American Journal of Physiology Regulatory, Integrative and Comparative Physiology 278 1415-1423.

Guo Y, Wang H, Okamoto Y, Ueda N, Kingsley PJ, Marnett LJ, Schmid HH, Das SK \& Dey SK 2005 N-acylphosphatidylethanolamine-hydrolyzing phospholipase $\mathrm{D}$ is an important determinant of uterine anandamide levels during implantation. Journal of Biological Chemistry 280 23429-23432. (doi:10.1074/jbc.C500168200)

Habayeb OM, Taylor AH, Evans MD, Cooke MS, Taylor DJ, Bell SC \& Konje JC 2004 Plasma levels of the endocannabinoid anandamide in women - a potential role in pregnancy maintenance and labor? Journal of Clinical Endocrinology and Metabolism 89 5482-5487. (doi:10.1210/jc.2004-0681)

Klein TW, Newton C, Larsen K, Lu L, Perkins I, Nong L \& Friedman H 2003 The cannabinoid system and immune modulation. Journal of Leukocyte Biology 74 486-496. (doi:10.1189/jlb.0303101)

Lazzarin N, Valensise H, Bari M, Ubaldi F, Battista N, Finazzi-Agrò A \& Maccarrone M 2004 Fluctuations of fatty acid amide hydrolase and anandamide levels during the human ovulatory cycle. Gynecological Endocrinology 18 212-218. (doi:10.1080/09513590410001692492)

Liu J, Batkai S, Pacher P, Harvey-White J, Wagner JA, Cravatt BF, Gao B \& Kunos G 2003 Lipopolysaccharide induces anandamide synthesis in macrophages via CD14/MAPK/phosphoinositide 3-kinase/NF-kappaB independently of platelet-activating factor. Journal of Biological Chemistry 278 45034-45039. (doi:10.1074/jbc.M306062200)

Maccarrone M 2009 Endocannabinoids: friends and foes of reproduction. Progress in Lipid Research 48 344-354. (doi:10.1016/j.plipres.2009. 07.001)

Maccarrone M, Valensise H, Bari M, Lazzarin N, Romanini C \& FinazziAgro A 2000 Relation between decreased anandamide hydrolase concentrations in human lymphocytes and miscarriage. Lancet 355 1326-1329. (doi:10.1016/S0140-6736(00)02115-2)

Maccarrone M, De Petrocellis L, Bari M, Fezza F, Salvati S, Di Marzo V \& Finazzi-Agrò A 2001 Lipopolysaccharide downregulates fatty acid amide 
hydrolase expression and increases anandamide levels in human peripheral lymphocytes. Archives of Biochemistry and Biophysics 393 321-328. (doi:10.1006/abbi.2001.2500)

Mendelson CR 2009 Minireview: fetal-maternal hormonal signaling in pregnancy and labor. Molecular Endocinology 23 947-954. (doi:10. 1210/me.2009-0016)

Mishra DP \& Dhali A 2007 Endotoxin induces luteal cell apoptosis through the mitochondrial pathway. Prostaglandins \& Other Lipid Mediators 83 75-88. (doi:10.1016/j.prostaglandins.2006.10.002)

Mitchell MD, Sato TA, Wang A, Keelan JA, Ponnampalam AP \& Glass M 2008 Cannabinoids stimulate prostaglandin production by human gestational tissues through a tissue- and CB1-receptor-specific mechanism. American Journal of Physiology-Endocrinology and Metabolism 294 352-356. (doi:10.1152/ajpendo.00495.2007)

Pacher P \& Mechoulam R 2011 Is lipid signaling through cannabinoid 2 receptors part of a protective system? Progress in Lipid Research $\mathbf{5 0}$ 193-211. (doi:10.1016/j.plipres.2011.01.001)

Paria BC, Das SK \& Dey SK 1995 The preimplantation mouse embryo is a target for cannabinoid ligand-receptor signaling. PNAS 92 9460-9464. (doi:10.1073/pnas.92.21.9460)

Paria BC, Deutsch DD \& Dey SK 1996 The uterus is a potential site for anandamide synthesis and hydrolysis: differential profiles of anandamide synthase and hydrolase activities in the mouse uterus during the periimplantation period. Molecular Reproduction and Development 45 183-192. (doi:10.1002/ (SICI)1098-2795(199610)45:2 <183::AID-MRD11 > 3.0.CO;2-2)

Park CW, Moon KC, Park JS, Jun JK \& Yoon BH 2009 The frequency and clinical significance of intrauterine infection and inflammation in patients with placenta previa and preterm labor and intact membranes. Placenta 30 613-618. (doi:10.1016/j.placenta.2009.04.005)

Piomelli D, Giuffrida A, Calignano A \& Rodríguez de Fonseca F 2000 The endocannabinoid system as a target for therapeutic drugs. Trends in Pharmacological Sciences 21 218-224. (doi:10.1016/S01656147(00)01482-6)

Rozen S \& Skaletsky HJ 2000 Primer3 on the WWW for general users and for biologist programmers. In Bioinformatics Methods and Protocols: Methods in Molecular Biology, pp 365-386. Eds S Krawetz \& S Misener. Totowa, NJ: Humana Press.

Schmid PC, Paria BC, Krebsbach RJ, Schmid HH \& Dey SK 1997 Changes in anandamide levels in mouse uterus are associated with uterine receptivity for embryo implantation. PNAS 94 4188-4192. (doi:10.1073/ pnas.94.8.4188)

Schuel H, Burkman LJ, Lippes J, Crickard K, Forester E, Piomelli D \& Giuffrida A $2002 \mathrm{~N}$-acylethanolamines in human reproductive fluids. Chemistry and Physics of Lipids 121 211-227. (doi:10.1016/S00093084(02)00158-5)

Shynlova O, Nedd-Roderique T, Li Y, Dorogin A \& Lye SJ 2013 Myometrial immune cells contribute to term parturition, preterm labour and postpartum involution in mice. Journal of Cellular and Molecular Medicine 7 90-102. (doi:10.1111/j.1582-4934.2012.01650.x)
Sun X, Cappelletti M, Li Y, Karp CL, Divanovic S \& Dey SK 2014 Cnr2 deficiency confers resistance to inflammation-induced preterm birth in mice. Endocrinology 155 4006-4014. (doi:10.1210/en.2014-1387)

Taylor AH, Ang C, Bell SC \& Konje JC 2007 The role of the endocannabinoid system in gametogenesis, implantation and early pregnancy. Human Reproduction Update 13 501-513. (doi:10.1093/ humupd/dmm018)

Timmons BC, Reese J, Socrate S, Ehinger N, Paria BC, Milne GL, Akins ML, Auchus RJ, McIntire D, House M \& Mahendroo M 2014 Prostaglandins are essential for cervical ripening in LPS-mediated preterm birth but not term or antiprogestin-driven preterm ripening. Endocrinology 155 287-298. (doi:10.1210/en.2013-1304)

Trabucco E, Acone G, Marenna A, Pierantoni R, Cacciola G, Chioccarelli T, Mackie K, Fasano S, Colacurci N, eccariello R et al. 2009 Endocannabinoid system in first trimester placenta: low FAAH and high CB1 expression characterize spontaneous miscarriage. Placenta 30 516-522. (doi:10.1016/j.placenta.2009.03.015)

Varga K, Wagner JA, Bridgen DT \& Kunos G 1998 Platelet- and macrophage-derived endogenous cannabinoids are involved in endotoxin-induced hypotension. Federation of American Societies for Experimental Biology 12 1035-1044. (doi:0892-6638/98/0012-1035)

Vercelli CA, Aisemberg J, Billi S, Cervini M, Ribeiro ML, Farina M \& Franchi AM 2009 Anandamide regulates lipopolysaccharide-induced nitric oxide synthesis and tissue damage in the murine uterus. Reproductive Biomedicine Online 18 824-831. (doi:10.1016/S14726483(10)60033-8)

Vercelli C, Wolfson M, Salazar Al, Osycka-Salut C, Billi S, Ribeiro ML, Farina M \& Franchi AM 2010 Inflammatory agents involved in septic miscarriage. Neuroimmunomodulation 17 150-152. (doi:10.1159/ 000258710)

Wang H, Xie H, Guo Y, Zhang H, Takahashi T, Kingsley PJ, Marnett LJ, Das SK, Cravatt BF \& Dey SK 2006 Fatty acid amide hydrolase deficiency limits early pregnancy events. Journal of Clinical Investigation $\mathbf{1 1 6}$ 2122-2131. (doi:10.1172/JCl28621)

Wang H, Xie H \& Dey SK 2008 Loss of cannabinoid receptor CB1 induces preterm birth. PLOS ONE 3 e3320. (doi:10.1371/journal.pone.0003320)

Wolfson ML, Aisemberg J, Salazar AI, Domínguez Rubio AP, Vercelli CA \& Franchi AM 2013 Progesterone reverts LPS-reduced FAAH activity in murine peripheral blood mononuclear cells by a receptor-mediated fashion. Molecular and Cellular Endocrinology $381 \quad 97-105$. (doi:10.1016/j.mce.2013.07.020)

Received 7 May 2015

First decision 15 June 2015

Revised manuscript received 11 August 2015

Accepted 7 September 2015 